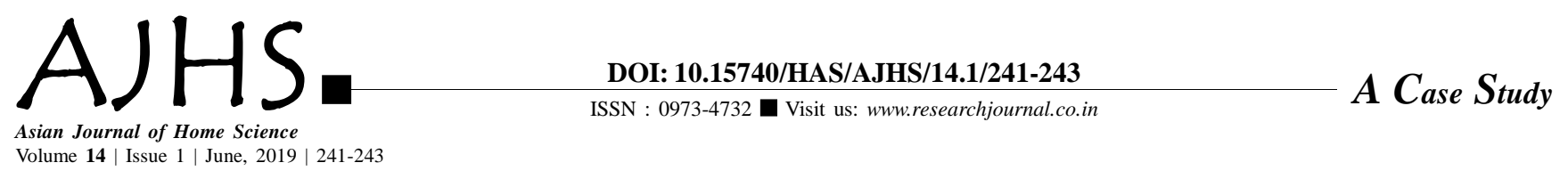

\title{
Attitude and perception towards death of family member
}

\section{Poppy Gogoi and Sampreety Gogoi}

Received: 28.02.2019; Accepted: 29.05 .2019

See end of the paper for authors' affiliations

\section{Poppy Gogoi}

Department of Human

Development and Family Studies, College of Community Science, Assam Agricultural University,

Jorhat (Assam) India

Email : poppygogoi94@gmail.

com
ABSTRACT : Death is the end process of life and one of the great certainty in life. Death has many taboos associated with it due to which people do not like to talk about it. The present case study was an attempt to understand the attitude and perception of people towards death and how they cope with it. Many people have suffered a loss and have shared their perception regarding death which helps to develop the core concept of death. The sample consisted of 30 people of different age group and sex which were selected randomly from Jorhat district of Assam. Data was collected through focus group discussion and a semi structured questionnaire was used to guide the discussion. It revealed that even though people refused to accept the death of near or dear one but they knows that death is inevitable so anyhow even though it takes time people try to come out from the grief.

KEY WORDS: Death, Dying, Attitude, Perception

- HOW TO CITE THIS PAPER : Gogoi, Poppy and Gogoi, Sampreety (2019). Attitude and perception towards death of family member. Asian J. Home Sci., 14 (1) : 241-243, DOI: 10.15740/HAS/AJHS/14.1/ 241-243. Copyright@ 2019: Hind Agri-Horticultural Society. 